\title{
Waterlogging Tolerance of Kentucky Bluegrass Cultivars
}

\author{
Kehua Wang ${ }^{1}$ and Yiwei Jiang, \\ Department of Agronomy, Purdue University, West Lafayette, IN 47907-2054
}

\begin{abstract}
Additional index words. physiological responses, Poa pratensis, soil saturation, turf quality
\end{abstract}
Abstract. Waterlogging (WL) affects the growth and physiological responses of turfgrass. The objectives of this study were to compare the relative WL tolerance of Kentucky bluegrass (Poa pratensis L.) cultivars and to investigate the physiological responses of shoots and roots to $W L$. Ten cultivars differing in growth habit were subjected to $30 \mathrm{~d}$ of WL. The turf quality (TQ) and soil redox potential (Eh), as well as the chlorophyll concentration (Chl), decreased with increasing periods of WL. Among all cultivars, root dry weight (RDW) decreased $16.7 \%$ to $39.9 \%$ under $10 \mathrm{~d}$ and $30.0 \%$ to $60 \%$ under $30 \mathrm{~d}$ of WL, respectively. Waterlogging increased the root electrolyte leakage (REL) from $0.6 \%$ to $53.2 \%$ under $10 \mathrm{~d}$ and from $29.1 \%$ to $98.0 \%$ under $30 \mathrm{~d}$ of $\mathrm{WL}$ for all cultivars, respectively. The best correlations were observed between Eh and TQ $(r=0.74)$, REL and TQ $(r=0.75)$, RDW and root water-soluble carbohydrate content (RWSC) $(r=0.74)$, and root oxidase activity and RWSC $(r=\mathbf{0 . 6 3})$, respectively. 'Moonlight', 'Serene', and 'Champagne' showed better tolerance to short-term WL conditions, whereas 'Kenblue' and 'Eagleton' were the least tolerant cultivars. 'Limousine', 'Unique', 'Awesome', 'Julia', and 'Midnight II' ranked in the middle group. Variations in WL tolerance among Kentucky bluegrasses could potentially be used for enhancing turfgrass management.

Waterlogging is defined as the saturation of the soil with water around the roots (Anton et al., 2002). Excess water in the root environment blocks the transfer of oxygen and other gases between the soil and the atmosphere; as a result, root injury occurs as a result of oxygen deficiency. Oxygen deficiency is one of the primary root stresses in the waterlogged or flooded soils (Kozlowski, 1984). Short-term or even transient waterlogging could have adverse effects on the growth of dry land plants (Condona and Giunta, 2003). Also, the intensity of stress increases during long-term waterlogging of up to weeks or months (Naidoo et al., 1992). Plant tolerance to waterlogging or flooding can vary from only several hours to days or weeks depending on the plant species.

Waterlogging stress and soil saturation happen in turfgrass as a result of high precipitation, poor soil quality, or overirrigation followed by slow drainage. The reduced soil oxygen availability under waterlogging decreased the turf quality, photosynthetic rate, and chlorophyll and carbohydrate concentration of turfgrass (Huang et al., 1998; Jiang and Wang, 2006). Although perennial grasses are considered to be tolerant to a shortage of oxygen induced by waterlogging or flooding (Jones and Etherington, 1970), large variations in waterlogging tolerance

Received for publication 12 Aug. 2006. Accepted for publication 8 Nov. 2006.

This research was supported by the Midwest Regional Turfgrass Foundation.

${ }^{1}$ Graduate Assistant.

${ }^{2}$ Assistant Professor.

${ }^{3}$ To whom reprint requests should be addressed; e-mail: yjiang@purdue.edu. occur in different turfgrass species and cultivars. Creeping bentgrass (Agrostis stolonifera L.) is relatively tolerant to waterlogginginduced hypoxia. However, creeping red fescue (Festuca rubra L.) is sensitive, and orchard grass (Dactylis glomerata L.) is unusually sensitive to waterlogging (Cooper, 1982; Gray and Scott, 1977). Fry (1991) reported that bahiagrass (Paspalum notatum Flügge) and bermudagrass (Cynodon dactylon L.) had higher shoot survival after submersion than did St. Augustinegrass [Stenotaphrum secundatum (Walt.) Kuntze] and zoysaigrass (Zoysia japonica Steud.), whereas centipedegrass [Eremochla ophiuroides (Munro) Hack.] showed no survival under the same stress condition. Within creeping bentgrass, tolerant cultivars of G-6 and L-93 showed less reduction in chlorophyll concentration and root dry weight than did the intolerant cultivars of Penncross and Pennlinks when the water level was at 15 or $1 \mathrm{~cm}$ below the soil surface (Jiang and Wang, 2006). A wide range in flood damage among perennial ryegrass cultivars was observed with 'All Star' and 'Premier' being relatively tolerant to flooding (Razmjoo et al., 1993). These results suggest that variations in the waterlogging tolerance of turfgrass species and cultivars are important for turfgrass management for selection of a grass for a particular use.

The physiological responses of plant species to waterlogged or flooded soil are diverse, including changes in nonstructural carbohydrate content (Barta, 1988; Castonguay et al., 1993; Su et al., 1998), antioxidant enzyme activity and isoenzyme profile (Biemelt et al., 2000; Lin et al., 2004), anaerobic metabolisms (Chen and Qualls, 2003;
Kennedy et al., 1992), expression of oxygenrelated stress protein (Dordas et al., 2003; Igamberdiev et al., 2004), and levels of plant hormones that include ethylene, abscisic acid, and cytokinin (Olivella et al., 2000; Schravendijk and Van Andel, 1986; Zhang and Davis, 1987). Some of these mechanisms may allow plants to adapt or be tolerant to oxygen deficiency to a certain degree; however, they are influenced by species and cultivars and the duration and depth of waterlogging stress as well as other environmental factors such as temperature. The responses of shoots and roots to waterlogging are not well documented in different turfgrass species or cultivars. Thus, more detailed research is needed to assess the waterlogging tolerance of turfgrass and to explore the physiological traits associated with stress tolerance.

Kentucky bluegrass (Poa pratensis L.) is a widely used turfgrass species that adapts to well-drained soil conditions over cool climate regions. Large variations in growth habits, leaf texture, color, and some stress resistance have been found in Kentucky bluegrass; however, little information is known about the waterlogging tolerance of this grass, except that reduced root growth is found under poor aeration conditions (Waddington and Baker, 1965). A better understanding of the diversity of waterlogging tolerance among cultivars would provide a basis for managing this grass and would further reveal the mechanisms of grass adaptation to saturated or flooded soils. Thus, the objectives of this study were to compare the relative waterlogging tolerance of Kentucky bluegrass cultivars and to investigate the physiological responses of shoots and roots to waterlogging.

\section{Materials and Methods}

Plant materials and growing conditions. The study was conducted in a greenhouse from Nov. 2005 to Mar. 2006. Ten cultivars of 5-year-old Kentucky bluegrass sod plugs were collected in the Fall of 2005 from the William H. Daniel Research and Diagnostic Center at Purdue University in West Lafayette, Ind. Various types of cultivars differing in growth habit were selected, including 'Limousine' and 'Awesome' (aggressive type), 'Moonlight' (compact type), 'Midnight II' (Midnight type), 'Unique' (America type), 'Julia' (Julia type), 'Eagleton' (MidAtlantic type), 'Serene' (Cheri type), 'Champagne' (Shamrock type), and 'Kenblue' (common type). The plugs were cut to $3-\mathrm{cm}$ thick and then grown in plastic pots with the volume of $785 \mathrm{~cm}^{3}$ containing topsoil and sand (1:1) for $90 \mathrm{~d}$. The topsoil had a $\mathrm{pH}$ of 6.9. The grasses were irrigated as necessary to prevent drought stress, mowed three times a week at $4 \mathrm{~cm}$ with electric handheld clippers, and fertilized weekly with watersoluble fertilizer of 20-20-20 (N- $\mathrm{P}_{2} \mathrm{O}_{5}$ $\mathrm{K}_{2} \mathrm{O}$ ) (Scotts-Sierra Horticultural Products Co., Marysville, Ohio) to provide $244 \mathrm{~kg} \cdot \mathrm{ha}^{-1}$ $\mathrm{N}, 107 \mathrm{~kg} \cdot \mathrm{ha}^{-1} \mathrm{P}$, and $202 \mathrm{~kg} \cdot \mathrm{ha}^{-1} \mathrm{~K}$ per year. 
The grasses were allowed to be well established before the waterlogging treatments began. During the experiment, the average air temperature in the greenhouse was $23^{\circ} \mathrm{C} /$ $17{ }^{\circ} \mathrm{C}$ (day/night). Supplemental light (12-h photoperiod) was added in the greenhouse along with natural light to provide an average photosynthetic photon flux of 600 $\mu \mathrm{mol} \cdot \mathrm{m}^{-2} \cdot \mathrm{s}^{-1}$ above the grass canopy during the entire experiment.

Waterlogging treatments. Grass pots were placed into containers with the volume of $35,360 \mathrm{~cm}^{3}$ full of water. The water level in each pot was kept at the soil surface. The water was changed every $5 \mathrm{~d}$ during the experiment. The treatments included: 1) control, welldrained to field capacity, and 2) waterlogged soil with water level at the soil surface.

Sampling and measurements. The turf quality (TQ) was visually rated as an integral of color, uniformity, and density on a scale of 1 (brown leaves) to 9 (turgid, green leaves) at $0,5,10,15,20$, and $30 \mathrm{~d}$ of waterlogging (WL) treatment. The soil redox potential (Eh) was measured using Combination Redox Probe (TPS Pty. Ltd., Brisbane, Australia). The probe was inserted $10-\mathrm{cm}$ deep below the soil surface and the reading was recorded after the probe was equilibrated in the soil. The leaves and roots were collected after WL at $10 \mathrm{~d}$ and $30 \mathrm{~d}$, respectively. The roots were then washed free of the soil. Both the leaves and roots were kept under ice and transferred to the laboratory for further analysis.

The leaves per pot were mixed and used for extraction of chlorophyll (Chl) according to the methods of Inskeep and Bloom (1985). The leaf Chl was extracted by soaking 20 to $40 \mathrm{mg}$ samples in $15 \mathrm{~mL}$ dimethyl sulfoxide in the dark for $48 \mathrm{~h}$. The absorbance was read at 662 and $645 \mathrm{~nm}$. The root electrolyte leakage was measured according to the method of Blum and Ebercon (1981) and Marcum (1998) with modifications. Fresh roots were excised and cut into $1-\mathrm{cm}$ segments. The detailed procedure of measuring the electrolyte leakage was described by Jiang and Huang (2001b). The oxidase activity of the roots was measured according to Ye et al. (2003). Briefly, 0.2 to $0.3 \mathrm{~g}$ fresh root samples were excised and immersed into a 20-mL solution containing a 1:1 mixture of $25 \mu \mathrm{g} \cdot \mathrm{mL}^{-1} \alpha$-naphthylamine and $0.1 \mathrm{M}$ phosphate buffer with a pH 7.0 and kept $25^{\circ} \mathrm{C}$ for $24-\mathrm{h}$ incubation. At the beginning and the end of incubation, the $0.2-\mathrm{mL}$ solution was added to $2 \mathrm{~mL}$ deionized water, $0.1 \mathrm{~mL}$ $1 \%$ sulfanilic acid (w/v in $30 \%$ acetic acid), and $0.1 \mathrm{~mL} 0.01 \%$ sodium nitrite. The mixture was kept at room temperature for $20 \mathrm{~min}$, and the absorbance at $510 \mathrm{~nm}$ was read. The activity of root oxidase was determined by the decrease of $\alpha$-naphthylamine during the incubation period. The root dry weight (RDW) was determined after the samples were dried in an oven at $80{ }^{\circ} \mathrm{C}$ for $3 \mathrm{~d}$. The oven-dried leaves and roots were used to determine shoot water-soluble carbohydrate content (SWSC) and root-soluble carbohydrate content (RWSC) using the methods of Dubois et al. (1956) modified by Buysse and
Merckx (1993). The detailed procedure of extraction and assay was described by Jiang and Huang (2001a). The percent change between the control and WL for each parameter was calculated as follows: change $(\%)=$ [(control-WL)/control] $\times 100$.

Experimental design and statistical analyses. The experiment was a randomized complete block design. Four blocks in the greenhouse were used representing the four replicates in this study. Each block contained the control and the WL treatment. Ten cultivars were arranged randomly in each treatment. Data from $10 \mathrm{~d}$ and $30 \mathrm{~d}$ of the treatment were used for the purpose of analyzing the differences in treatments and cultivars using SAS (SAS Institute, 1987). The means of each trait for the treatment and the cultivar were separated using Fisher's least significant difference at a 0.05 significance level.

\section{Results}

The analysis of the data determined the importance of the cultivar, WL, and their interaction effects (Table 1). Significant cultivar effects were observed for all traits except for SWSC at $10 \mathrm{~d}$ of treatment. Significant treatment effects were also noted for all traits except for RWSC at $10 \mathrm{~d}$ of treatment. Significant cultivar $\times$ WL interactions were observed for TQ at both $10 \mathrm{~d}$ and $30 \mathrm{~d}$ of treatments and for SWSC and RWSC at $30 \mathrm{~d}$ of treatment, respectively.

Waterlogging effects. The Eh was reduced on average from 412 to $24 \mathrm{mV}$ and from 380 to $-17 \mathrm{mV}$ at $10 \mathrm{~d}$ and $30 \mathrm{~d}$ of WL in all cultivars, respectively. The soil $\mathrm{pH}$ decreased from 7.2 to 6.6 after $30 \mathrm{~d}$ of WL for all cultivars. Waterlogging significantly decreased TQ for all cultivars (Tables 2 and 3). The Chl concentration was significantly reduced by $10 \mathrm{~d}$ of WL in 'Moonlight', 'Midnight II', and 'Kenblue'; however, significant reductions in Chl concentration were observed in all cultivars under $30 \mathrm{~d}$ of WL treatments. Reductions in RDW were observed in the cultivars of 'Awesome', 'Limousine', 'Julia', and 'Eagleton' under 10 of WL and in eight cultivars under $30 \mathrm{~d}$ of WL. Significant increases in root electrolyte leakage (REL) were observed in the cultivars of 'Eagleton' and 'Kenblue', whereas five cultivars showed an increase in REL at $30 \mathrm{~d}$ of WL.

Table 1. Analysis of variance of turf quality (TQ), chlorophyll concentration (Chl), shoot water-soluble carbohydrate content (SWSC), root water-soluble carbohydrate content (RWSC), root electrolyte leakage (REL), root oxidase activity (ROA), and root dry weight (RDW) at 10 and 30 d of waterlogging in Kentucky bluegrass.

\begin{tabular}{lllllllll}
\hline Duration (d) & \multicolumn{1}{c}{ Variance } & TQ & Chl & SWSC & RWSC & REL & ROA & RDW \\
\hline 10 & Cultivar (C) & $* * *$ & $* * *$ & NS & $* * *$ & $* * *$ & $* * *$ & $*$ \\
& Waterlogging (WL) & $* * *$ & $* *$ & $* * *$ & NS & $*$ & $* * *$ & $* * *$ \\
& C $\times$ WL & $* * *$ & NS & NS & NS & NS & NS & NS \\
30 & Cultivar (C) & $* * *$ & $* * *$ & $* * *$ & $* * *$ & $* * *$ & $* * *$ & $*$ \\
& Waterlogging (WL) & $* * *$ & $* * *$ & $* * *$ & $* * *$ & $* * *$ & $* * *$ & $* * *$ \\
& C $\times$ WL & $* * *$ & NS & $*$ & $*$ & NS & NS & NS \\
\hline NS, $* * * * *, *$ Nonsignificant or mean significant level at $P<0.001,0.01,0.05$, respectively. & &
\end{tabular}

Table 2. Effects of $10 \mathrm{~d}$ of waterlogging on turf quality (TQ), chlorophyll concentration (Chl), shoot watersoluble carbohydrate content (SWSC), root water-soluble carbohydrate content (RWSC), root electrolyte leakage (REL), root oxidase activity (ROA), and root dry weight (RDW) in Kentucky bluegrass cultivars.

\begin{tabular}{|c|c|c|c|c|c|c|c|c|}
\hline Cultivars & Treatment & TQ & $\begin{array}{c}\text { Chl } \\
\left(\mathrm{mg} \cdot \mathrm{g}^{-1} \mathrm{FW}\right)\end{array}$ & $\begin{array}{c}\text { SWSC } \\
\left(\mathrm{mg} \cdot \mathrm{g}^{-1} \mathrm{DW}\right)\end{array}$ & $\begin{array}{c}\text { RWSC } \\
\left(\mathrm{mg} \cdot \mathrm{g}^{-1} \mathrm{DW}\right)\end{array}$ & $\begin{array}{l}\text { REL } \\
(\%)\end{array}$ & $\begin{array}{c}\text { ROA } \\
\left(\mu \mathrm{g} \cdot \mathrm{h}^{-1} \cdot \mathrm{g}^{-1} \mathrm{FW}\right)\end{array}$ & $\begin{array}{c}\text { RDW } \\
(\mathrm{g})\end{array}$ \\
\hline \multirow[t]{2}{*}{$\overline{\text { Moonlight }}$} & $\mathrm{CL}^{\mathrm{z}}$ & 7.9 & 3.12 & 78.3 & 117.0 & 11.5 & 37.5 & 0.33 \\
\hline & $\mathrm{WL}^{\mathrm{y}}$ & $7.4 *$ & $2.51 *$ & 79.8 & 106.2 & 11.6 & 50.2 & 0.24 \\
\hline \multirow[t]{2}{*}{ Midnight II } & $\mathrm{CL}$ & 7.8 & 3.17 & 88.0 & 33.3 & 18.9 & 33.9 & 0.22 \\
\hline & WL & $7.1^{*}$ & $2.78 *$ & $58.8^{*}$ & 40.2 & 17.2 & 35.2 & 0.17 \\
\hline \multirow[t]{2}{*}{ Serene } & $\mathrm{CL}$ & 7.6 & 2.88 & 84.4 & 69.9 & 11.9 & 36.7 & 0.33 \\
\hline & WL & $7.1^{*}$ & 2.64 & 65.1 & 70.9 & 12.8 & 26.2 & 0.26 \\
\hline \multirow[t]{2}{*}{ Champagne } & $\mathrm{CL}$ & 7.6 & 2.70 & 93.5 & 66.9 & 15.7 & 30.7 & 0.27 \\
\hline & WL & $7.1^{*}$ & 2.46 & $68.2 *$ & 66.3 & 15.8 & 30.2 & 0.18 \\
\hline \multirow[t]{2}{*}{ Unique } & $\mathrm{CL}$ & 7.6 & 2.84 & 102.9 & 70.1 & 13.6 & 27.9 & 0.24 \\
\hline & WL & $6.7 *$ & 2.53 & $66.5^{*}$ & 68.3 & 16.3 & 25.4 & 0.20 \\
\hline \multirow[t]{2}{*}{ Awesome } & CL & 7.6 & 3.12 & 85.4 & 35.4 & 20.3 & $29.4 *$ & 0.23 \\
\hline & WL & $6.9^{*}$ & 3.16 & 74.8 & 43.3 & 18.9 & 36.3 & $0.15^{*}$ \\
\hline \multirow[t]{2}{*}{ Limousine } & $\mathrm{CL}$ & 7.5 & 2.70 & 97.3 & 42.2 & 13.5 & 27.7 & 0.26 \\
\hline & WL & $7.2^{*}$ & 2.83 & $62.9 *$ & 46.3 & 14.6 & 30.3 & $0.18 *$ \\
\hline \multirow[t]{2}{*}{ Julia } & $\mathrm{CL}$ & 7.5 & 2.82 & 85.8 & 59.5 & 14.5 & 22.1 & 0.26 \\
\hline & WL & $6.9^{*}$ & 2.65 & $62.2 *$ & 67.6 & 14.7 & 32.9 & $0.18 *$ \\
\hline \multirow[t]{2}{*}{ Eagleton } & CL & 7.4 & 2.41 & 97.3 & 58.2 & 11.1 & 29.2 & 0.27 \\
\hline & WL & $6.9^{*}$ & 2.29 & $58.0^{*}$ & 50.6 & $17.0^{*}$ & 41.3 & $0.16^{*}$ \\
\hline \multirow[t]{2}{*}{ Kenblue } & $\mathrm{CL}$ & 6.7 & 2.62 & 74.2 & 40.2 & 16.7 & 27.4 & 0.29 \\
\hline & WL & $5.5^{*}$ & $2.34 *$ & 62.7 & 50.4 & $22.5^{*}$ & 31.9 & 0.22 \\
\hline
\end{tabular}

${ }^{\mathrm{z} C L}=$ control, well drained.

${ }^{\mathrm{y}} \mathrm{WL}=$ waterlogging.

* Significant at $P<0.05$ between $\mathrm{CL}$ and WL at a given cultivar. 
Table 3. Effects of $30 \mathrm{~d}$ of waterlogging on turf quality (TQ), chlorophyll concentration (Chl), shoot watersoluble carbohydrate content (SWSC), root water-soluble carbohydrate content (RWSC), root electrolyte leakage (REL), root oxidase activity (ROA), and root dry weight (RDW) in Kentucky bluegrass cultivars.

\begin{tabular}{|c|c|c|c|c|c|c|c|c|}
\hline Cultivars & Treatment & TQ & $\begin{array}{c}\mathrm{Chl} \\
\left(\mathrm{mg} \cdot \mathrm{g}^{-1} \mathrm{FW}\right)\end{array}$ & $\begin{array}{c}\text { SWSC } \\
\left(\mathrm{mg} \cdot \mathrm{g}^{-1} \mathrm{DW}\right)\end{array}$ & $\begin{array}{c}\text { RWSC } \\
\left(\mathrm{mg} \cdot \mathrm{g}^{-1} \mathrm{DW}\right)\end{array}$ & $\begin{array}{l}\text { REL } \\
(\%)\end{array}$ & $\begin{array}{c}\text { ROA } \\
\left(\mu \mathrm{g} \cdot \mathrm{h}^{-1} \cdot \mathrm{g}^{-1} \mathrm{FW}\right)\end{array}$ & $\begin{array}{c}\text { RDW } \\
(\mathrm{g})\end{array}$ \\
\hline \multirow{2}{*}{ Moonlight } & $\mathrm{CL}^{\mathrm{z}}$ & 7.9 & 2.56 & $164.7^{*}$ & 168.6 & 12.1 & 53.6 & 0.58 \\
\hline & $\mathrm{WL}^{\mathrm{y}}$ & $6.2^{*}$ & $1.92 *$ & 242.6 & $96.8^{*}$ & $17.7 *$ & 43.0 & $0.30^{*}$ \\
\hline \multirow[t]{2}{*}{ Midnight II } & CL & 7.6 & 2.49 & 129.5 & 79.5 & 16.5 & 39.6 & 0.39 \\
\hline & WL & $6.2^{*}$ & $2.10^{*}$ & 140.0 & $49.1^{*}$ & 21.3 & 32.0 & $0.20 *$ \\
\hline \multirow[t]{2}{*}{ Serene } & CL & 7.4 & 2.29 & $137.8^{*}$ & 134.4 & 11.0 & 49.9 & 0.57 \\
\hline & WL & $6.4^{*}$ & $1.79 *$ & 149.0 & $76.4^{*}$ & 15.8 & 37.9 & $0.33^{*}$ \\
\hline \multirow[t]{2}{*}{ Champagne } & CL & 7.6 & 2.14 & 131.6 & 91.8 & 15.0 & 37.2 & 0.49 \\
\hline & WL & $6.2 *$ & $1.66^{*}$ & 157.5 & $70.5^{*}$ & 21.4 & 28.3 & $0.25^{*}$ \\
\hline \multirow[t]{2}{*}{ Unique } & CL & 7.5 & 2.21 & 178.3 & 114.9 & 11.7 & 38.1 & 0.44 \\
\hline & WL & $6.1^{*}$ & $1.59 *$ & 176.6 & $80.8^{*}$ & 18.1 & 33.2 & $0.22 *$ \\
\hline \multirow[t]{2}{*}{ Awesome } & CL & 7.6 & 2.61 & 141.4 & 63.4 & 16.0 & 40.5 & 0.45 \\
\hline & WL & $6.1^{*}$ & $2.10^{*}$ & 155.3 & 57.6 & $21.7^{*}$ & 35.7 & $0.18^{*}$ \\
\hline \multirow[t]{2}{*}{ Limousine } & CL & 7.5 & 2.40 & 129.9 & 95.6 & 12.3 & 43.2 & 0.50 \\
\hline & WL & $6.1^{*}$ & $1.81 *$ & 168.1 & 70.0 & $18.5^{*}$ & $28.5^{*}$ & $0.22 *$ \\
\hline \multirow[t]{2}{*}{ Julia } & $\mathrm{CL}$ & 7.5 & 2.22 & 135.0 & 117.9 & 9.0 & 32.9 & 0.41 \\
\hline & WL & $5.9^{*}$ & $1.48^{*}$ & 145.9 & 94.7 & $17.1 *$ & 29.7 & $0.27 *$ \\
\hline \multirow[t]{2}{*}{ Eagleton } & CL & 7.3 & 2.03 & 106.6 & 100.7 & 9.8 & 48.1 & 0.44 \\
\hline & WL & $5.8^{*}$ & $1.55^{*}$ & 118.2 & $77.2^{*}$ & $19.4^{*}$ & 41.5 & $0.32 *$ \\
\hline \multirow[t]{2}{*}{ Kenblue } & CL & 6.5 & 1.82 & 78.8 & 75.8 & 17.3 & 37.1 & 0.40 \\
\hline & WL & $4.8^{*}$ & $1.26^{*}$ & 100.2 & $51.8^{*}$ & $26.1 *$ & $23.1^{*}$ & $0.28 *$ \\
\hline
\end{tabular}

${ }^{{ }^{2} \mathrm{CL}}=$ control, well drained.

${ }^{\mathrm{y}} \mathrm{WL}=$ waterlogging.

*Significant at $P<0.05$ between CL and WL at a given cultivar.

Table 4. The percentage changes in turf quality (TQ), chlorophyll concentration (Chl), shoot water-soluble carbohydrate content (SWSC), shoot water-soluble carbohydrate content (RWSC), root dry weight (RDW), root oxidase activity (ROA), and root electrolyte leakage (REL) for Kentucky bluegrass under $10 \mathrm{~d}$ of waterlogging compared with grasses under a well-drained condition.

\begin{tabular}{|c|c|c|c|c|c|c|c|}
\hline \multirow[b]{2}{*}{ Cultivar } & \multicolumn{5}{|c|}{ Decreased (\%) } & \multicolumn{2}{|c|}{ Increased (\%) } \\
\hline & TQ & Chl & SWSC & RWSC & RDW & $\overline{\mathrm{ROA}}$ & REL \\
\hline$\overline{\text { Moonlight }}$ & 6.3 & 19.5 & $1.9 \uparrow$ & 9.2 & 27.3 & 33.9 & 0.9 \\
\hline Serene & 9.0 & 8.3 & 22.9 & $1.4 \uparrow$ & 21.2 & 35.5 & 7.6 \\
\hline Limousine & 6.6 & 4.9 & 35.4 & $9.7 \uparrow$ & 30.8 & 9.4 & 8.1 \\
\hline Awesome & 6.6 & 1.2 & 12.4 & $22.3 \uparrow$ & 34.8 & 23.5 & 6.9 \\
\hline Unique & 11.8 & 10.9 & 35.4 & 2.6 & 16.7 & $9.0 \downarrow$ & 19.9 \\
\hline Eagleton & 9.2 & 5.0 & 40.4 & 13.1 & 39.9 & 41.4 & 53.2 \\
\hline Champagne & 4.0 & 8.9 & 27.1 & 0.9 & 33.3 & $1.6 \downarrow$ & 0.6 \\
\hline Julia & 8.0 & 6.0 & 27.5 & $13.6 \uparrow$ & 30.8 & 48.8 & 1.4 \\
\hline Midnight II & 8.1 & 12.3 & 33.2 & $20.3 \uparrow$ & 22.7 & 3.8 & 9.0 \\
\hline Kenblue & 17.9 & 10.7 & 15.5 & 25.4 & 24.1 & 16.4 & 34.7 \\
\hline
\end{tabular}

$\uparrow=$ increased percentage

$\downarrow=$ decreased percentage.

Table 5. The percentage changes in turf quality (TQ), chlorophyll concentration (Chl), shoot water-soluble carbohydrate content (SWSC), shoot water-soluble carbohydrate content (RWSC), root dry weight (RDW), root oxidase activity (ROA), and root electrolyte leakage (REL) for Kentucky bluegrass under $30 \mathrm{~d}$ of waterlogging compared with grasses under a well-drained condition.

\begin{tabular}{lcccccrr}
\hline & \multicolumn{3}{c}{ Decreased (\%) } & & \multicolumn{2}{c}{ Increased (\%) } \\
\cline { 2 - 5 } \cline { 3 - 6 } Cultivar & TQ & Chl & RWSC & RDW & ROA & SWSC & REL \\
\hline Moonlight & 21.5 & 25.0 & 42.6 & 48.3 & 19.8 & 47.3 & 46.3 \\
Serene & 18.4 & 21.6 & 43.2 & 42.1 & 20.0 & 8.1 & 43.6 \\
Limousine & 13.5 & 24.6 & 26.8 & 56.0 & 34.0 & 29.4 & 50.4 \\
Awesome & 18.4 & 19.5 & 9.1 & 60.0 & 35.5 & 2.6 & 35.6 \\
Unique & 18.7 & 28.1 & 29.7 & 50.0 & 12.9 & 1.0 & 54.7 \\
Eagleton & 18.7 & 23.6 & 23.3 & 27.3 & 13.7 & 10.9 & 98.0 \\
Champagne & 18.7 & 22.4 & 23.2 & 49.0 & $23.9 \uparrow$ & 19.7 & 42.7 \\
Julia & 25.3 & 33.3 & 19.7 & 34.1 & 9.7 & 8.1 & 90.0 \\
Midnight II & 20.5 & 15.7 & 38.2 & 48.7 & 19.2 & 7.5 & 29.1 \\
Kenblue & 26.2 & 30.8 & 31.7 & 30.0 & 37.7 & 27.2 & 50.9 \\
\hline
\end{tabular}

$\uparrow=$ increased percentage.

Cultivar variations. Kentucky bluegrass cultivars differed in various physiological traits under the WL conditions compared with the well-drained control (Tables 4 and 5). At $10 \mathrm{~d}$ of WL, TQ was reduced $4 \%$ to $6 \%$ (the best) to $18 \%$ (the worst) among the cultivars. 'Kenblue' had the highest reductions in TQ and RWSC, whereas 'Awesome' had the lowest reductions in Chl under $10 \mathrm{~d}$ of WL. The patterns of RWSC were not consistent because five cultivars showed reductions, whereas the other five cultivars showed increases in RWSC. REL increased $1 \%$ to $2 \%$ (the best) to $53 \%$ (the worst) at $10 \mathrm{~d}$ of WL, and 'Moonlight' had the least increase in REL. At $30 \mathrm{~d}$ of WL, TQ was reduced $14 \%$ (the best) to $26 \%$ (the worst), and 'Kenblue' had the highest reductions in TQ. RWSC was reduced $9 \%$ (the best) to $43 \%$ (the worst) and RDW reduced $27 \%$ (the best) to $60 \%$ (the worst), respectively. 'Awesome' and 'Eagleton' had the lowest reduction in RWSC and RDW, respectively. REL increased $29 \%$ (the best) to $98 \%$ (the worst) at $30 \mathrm{~d}$ of WL treatment among the cultivars.

Quality decline over time. The reductions in TQ increased with increasing periods of WL in all cultivars (Fig. 1). Among all the cultivars, TQ decreased from $5 \%$ to $17 \%$ and $14 \%$ to $26 \%$ at $10 \mathrm{~d}$ and $30 \mathrm{~d}$ of WL, respectively. At day 10, 'Moonlight' exhibited the highest quality followed by 'Limousine', 'Serene', 'Champagne', and 'Midnight II', whereas 'Kenblue' had the lowest quality. At day 30, 'Serene' had the best quality followed by 'Champagne', 'Midnight II', 'Moonlight', 'Awesome', and 'Limousine'. Most cultivars maintained a minimum acceptable quality rating of 6 after $30 \mathrm{~d}$ of WL, except for 'Kenblue', 'Julia', and 'Eagleton'.

Correlations among traits. Under both the well-drained and the WL conditions, soil Eh was correlated with TQ, Chl, REL, and RDW (Table 6). REL was correlated with all traits except for SWSC. RDW was correlated with all traits except for Chl. Root oxidase activity (ROA) was correlated with all root physiological parameters. The best correlations were observed between Eh and TQ ( $r=$ $0.74)$, TQ and REL $(r=0.75)$, RDW and RWSC $(r=0.74)$, and ROA and RWSC $(r=0.63)$, respectively.

\section{Discussion}

Variations in TQ and physiological traits among Kentucky bluegrass cultivars under the WL conditions indicated a genetic diversity of this grass. Although significant cultivar $\times$ WL interactions were observed in TQ, the responses of TQ to WL across cultivars were scale changes, not in the direction of rank changes (Fig. 1). Interactions by cultivar $\times$ WL for SWSC and RWSC under $30 \mathrm{~d}$ of WL were also primarily incited by changes in scale among grasses. These interactions might have been affected by factors such as temperature and light during the experiment, which might have caused some grasses to respond differently to WL. The ranking of cultivar performance could be affected by the duration of the WL condition, indicating a characteristic of WL effects on physiological responses. Diversity of WL or flooding tolerance was also shown within perennial ryegrass (Razmjoo et al., 1993), creeping bentgrass (Jiang and Wang, 2006), and in different warm-season turfgrass species (Fry, 1991). Research on the assessment of WL tolerance in different turf species and cultivars would aid in turfgrass management for a better selection of grass. 


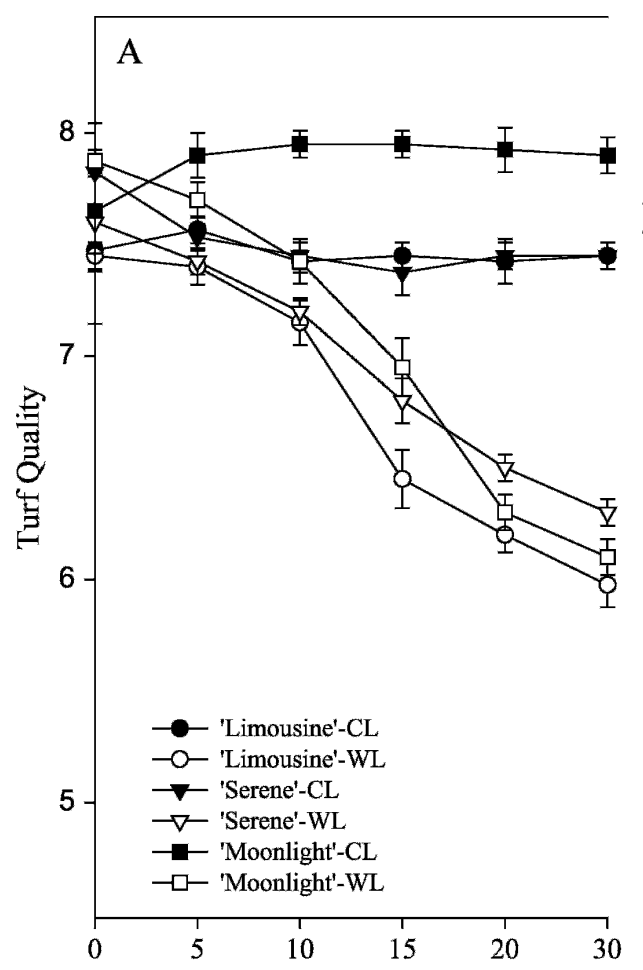

\section{B}

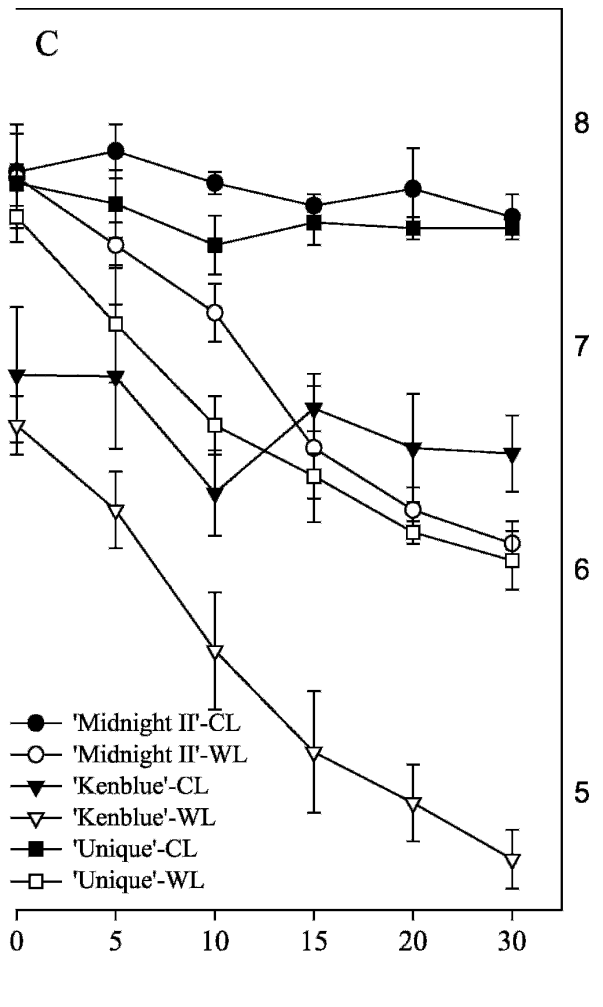

Fig. 1. Effects of waterlogging on turf quality in Kentucky bluegrass cultivars. CL = well-drained control; WL = waterlogging. Part A included 'Limousine', 'Serene', and 'Moonlight'; part B included 'Eagleton', 'Julia', 'Champagne', and 'Awesome'; and part C included 'Midnight II', 'Kenblue', and 'Unique'.

Table 6. The Pearson correlation coefficients and significant levels for turf quality (TQ), soil redox potential (Eh), chlorophyll concentration (Chl), shoot water-soluble carbohydrate content (SWSC), root water-soluble carbohydrate content (RWSC), root electrolyte leakage (REL), root oxidase activity (ROA), and root dry weight (RDW) for all Kentucky bluegrass cultivars under well-drained and waterlogging conditions.

\begin{tabular}{lcclccccc}
\hline Parameters & Eh & TQ & Chl & SWSC & REL & ROA & RWSC & RDW \\
\hline Eh & & $0.74^{* * *}$ & $0.47^{* *}$ & NS & $-0.54^{* * *}$ & NS & NS & $0.58^{* * *}$ \\
TQ & $0.74^{* * *}$ & & $0.74^{* * *}$ & NS & $-0.75^{* * *}$ & NS & NS & $0.37^{*}$ \\
Chl & $0.47^{* * *}$ & $0.74^{* * *}$ & & $-0.54^{* * *}$ & $-0.35^{*}$ & NS & NS & NS \\
SWSC & NS & NS & $-0.54^{* * *}$ & & NS & $0.31^{*}$ & $0.49^{* *}$ & $0.43^{* *}$ \\
REL & $-0.54^{* * *}$ & $-0.75^{* * *}$ & $-0.35^{* *}$ & NS & & $-0.32^{*}$ & $-0.57^{* * *}$ & $-0.49^{* *}$ \\
ROA & NS & NS & NS & $0.31^{*}$ & $-0.32^{*}$ & & $0.63^{* * *}$ & $0.51^{* * *}$ \\
RWSC & NS & NS & NS & $0.49^{* *}$ & $-0.57^{* * *}$ & $0.63^{* * *}$ & & \\
RDW & $0.58^{* * *}$ & $0.37^{*}$ & NS & $0.43^{* *}$ & $-0.49^{* *}$ & $0.51^{* * *}$ & $0.74^{* * *}$ & \\
\hline
\end{tabular}

Ns,***,**,*Nonsignificant or mean significant level at $P<0.001,0.01,0.05$, respectively.

The duration of stress is always a factor in determining stress tolerance. Jiang and Wang (2006) reported that WL continuously decreased TQ in creeping bentgrass with increasing WL intensity. Similar results in Kentucky bluegrass cultivars supported this conclusion (Fig. 1). 'Moonlight', 'Serene', and 'Champagne' had lower reductions in TQ than other cultivars when WL occurred during the first $10 \mathrm{~d}$, suggesting these cultivars might be a better choice for grass adaptation to short-term WL or soil saturation. Our results also showed that 'Kenblue' was a WL-sensitive cultivar as evidenced by the highest reductions in TQ at both 10 and $30 \mathrm{~d}$ of WL, whereas most of the other cultivars still maintained an acceptable quality of 6.0. The Chl concentration decreased with increasing WL, particularly in the lower leaves, which may contribute to a decline in TQ. Chlorophyll stability is known to be associated with stress tolerance, and a decrease in chlorophyll concentration may be the result of increased chlorophyllase activity under submergence (Ella and Ismail, 2006). 'Moonlight' had a larger reduction in Chl at $10 \mathrm{~d}$ of WL, but other physiological parameters observed in this cultivar such as lower REL and higher SWSC may contribute to its better WL tolerance.

The electrolyte leakage is an indicator of cell membrane stability and is widely used to screen or evaluate plant species or cultivars tolerant to temperature and water stresses (Blum and Ebercon, 1981; Sapra and Anaele, 1991). In general, an increased electrolyte leakage is considered an index of membrane damage and deterioration (Simon, 1974). Although WL increased REL in all 10 cultivars, the REL in 'Moonlight' and 'Champagne' was $\approx 30 \%$ lower than in 'Kenblue' and $50 \%$ lower than in 'Eagleton' at $10 \mathrm{~d}$ of WL. The lower REL in these cultivars indicated their capabilities to maintain root cell membrane stability and contributed to their better WL tolerance. REL was well correlated with all traits except for SWSC and was highly correlated with TQ $(r=0.75)$ in this study. These results demonstrated REL can be used as one of the parameters for evaluating the root injury occurring as a result of oxygen deficiency and for identifying the WL tolerance among different turfgrass species and cultivars.

Waterlogging affects the metabolic activity of the roots. The oxidase activity (oxidation of $\alpha$-naphthylamine) represents oxygen diffusion to the immediate vicinity of the roots and the power of oxidation in the root tissue (Ota, 1970). Ye et al. (2003) found ROA was unaffected by eight weeks of WL but increased during 12 weeks of WL in the tolerant mangrove species and decreased in the intolerant species. At $10 \mathrm{~d}$ of WL, ROA increased in most of the cultivars, but to a greater extent in 'Julia', 'Eagleton', 'Moonlight', and 'Serene'. The increased ROA may indicate an increased energy need for maintaining root activity to survive the short-term WL. However, ROA decreased after $30 \mathrm{~d}$ of WL in most of the cultivars, and 'Kenblue' showed $\approx 38 \%$ reduction in ROA. The decreased ROA under the extended period of WL suggested a further decline in the root metabolic activity of Kentucky bluegrass, which was associated with decreased RWSC $(r=0.63)$ and RDW $(r=0.51)$.

Root dry weight is sensitive to oxygen deficiency. Poor soil aeration reduces root growth in Kentucky bluegrass (Waddington 
and Baker, 1965) and WL decreases RDW in creeping bentgrass (Jiang and Wang, 2006). Reductions in RDW were also observed in Kentucky bluegrass in this study. 'Eagleton' showed the highest reduction in RDW in $10 \mathrm{~d}$ of WL, suggesting its intolerant characteristics under the WL condition. Changes in RDW could be associated with alterations in RWSC under WL conditions. Leul and Zhou (1999) reported that WL increased leaf and stem-soluble sugar content in Oilseed rape (Brassica napus), and similar results were observed in creeping bentgrass under the WL condition (Jiang and Wang, 2006). These results suggested that a reduction in WSC under WL is one of the major factors contributing to decreased root growth and insufficient energy supply. However, SWSC increased and RWSC decreased after $30 \mathrm{~d}$ of WL in Kentucky bluegrass, indicating that a shift in carbon allocation from belowground parts to above-ground parts with increasing WL may be responsible for the decline in root activity in grasses. A further study is needed to determine alterations in individual sugar in WL-tolerant and -intolerant cultivars in turfgrass.

In conclusion, Kentucky bluegrass cultivars exhibited a wide range of WL tolerance. Although variations exhibited in all cultivars based on traits measured in this study, 'Moonlight', 'Serene', and 'Champagne' showed better tolerance under the short-term WL condition. 'Kenblue' and 'Eagleton' were the least tolerant cultivars. 'Unique', 'Awesome', 'Limousine', 'Julia', and 'Midnight II' ranked in the middle group. Waterlogging decreased TQ, Chl, and RDW but increased REL in Kentucky bluegrass. REL was highly correlated with TQ and could be used for assessing WL tolerance. ROA was correlated with RWSC and RDW and could serve as an indicator of root metabolic activity under WL conditions.

\section{Literature Cited}

Anton, J.M., C.H. Marjolein, J.B. Joris, A.M. Robert, B. Jordi, and A.C. Laurentius. 2002. Submergence research using Rumex palustris as a model: Looking back and going forward. J. Exp. Bot. 53:391-398.

Barta, A.L. 1988. Response of field grown alfalfa to root waterlogging and shoot removal. I. Plant injury and carbohydrate and mineral content of roots. Agron. J. 80:889-892.

Biemelt, S., U. Keetman, H.P. Mock, and B. Grimm. 2000. Expression and activity of isoenzymes of superoxide dismutase in wheat roots in response to hypoxia and anoxia. Plant Cell Environ. 23:135-144.
Blum, A. and A. Ebercon. 1981. Cell membrane stability as a measure of drought and heat tolerance in wheat. Crop Sci. 21:43-47.

Buysse, J. and R. Merckx. 1993. An improved colorimetric method to quantify sugar content of plant tissue. J. Expt. Bot. 49:1361-1370.

Castonguay, Y., P. Nadeau, and R.R. Simard. 1993. Effects of flooding on carbohydrate and ABA levels in roots and shoots of alfalfa. Plant Cell Environ. 16:695-702.

Chen, H. and R.G. Qualls. 2003. Anaerobic metabolism in the roots of seedlings of the invasive exotic Lepidium latifolium. Environ. Exp. Bot. 50:29-40.

Condona, A.G. and F. Giunta. 2003. Yield response of restricted-tillering wheat to transient waterlogging on duplex soils. Aust. J. Agr. Res. 54:957-967.

Cooper, A. 1982. The effects of salinity and waterlogging on the growth and cation uptake of salt-marsh plants. New Phytol. 90:263-275.

Dordas, C., B.B. Hasinoff, A.U. Igamberdiev, N Manac'h, J. Rivoal, and R.D. Hill. 2003. Expression of a stress-induced haemoglobin affects NO levels produced by alfalfa under hypoxia stress. Plant J. 35:763-770.

Dubois, M., K.A. Gilles, J.K. Hamilton, P.A. Rebers, and F. Smith. 1956. Colorimetric method for determination of sugars and related substances. Anal. Chem. 28:350-356.

Ella, E.S. and A.M. Ismail. 2006. Seedling nutrient status before submergence affects survival after submergence in rice. Crop Sci. 46:1673-1681.

Fry, J.D. 1991. Submission tolerance of warmseason turfgrasses. HortScience 26:927.

Gray, A.J. and R. Scott. 1977. Ecology of Morecambe Bay. VII. Distribution of Puccinellia maritima, Festuca rubra and Agrostis stolonifera in salt marshes. J. Appl. Ecol. 14:229-241.

Huang, B., X. Liu, and J.D. Fry. 1998. Effects of high temperature and poor soil aeration on growth and viability of creeping bentgrass. Crop Sci. 38:1618-1622.

Igamberdiev, A.U., C. Seregélyes, N. Manac'h, and R.D. Hill. 2004. NADH-dependent metabolism of nitric oxide in alfalfa root cultures expressing barley haemoglobin. Planta 219:95102.

Inskeep, W.P. and P.R. Bloom. 1985. Extinction coefficients of chlorophyll $\mathrm{a}$ and $\mathrm{b}$ in N,Ndimethylformamide and $80 \%$ acetone. Plant Physiol. 77:483-485.

Jiang, Y. and B. Huang. 2001a. Osmotic adjustment and root growth associated with drought preconditioning-enhanced heat tolerance in Kentucky bluegrass. Crop Sci. 41:1168-1173.

Jiang, Y. and B. Huang. 2001b. Physiological responses to heat stress alone or in combination with drought: A comparison between tall fescue and perennial ryegrass. HortScience 36:682-686.

Jiang, Y. and K. Wang. 2006. Growth, physiological and anatomical responses of creeping bentgrass cultivars to different depths of waterlogging. Crop Sci. 46:2420-2426.
Jones, H.E. and J.R. Etherington. 1970. Comparative studies of plant-growth and distribution in relation to waterlogging. I. The survival of Erica cinerea $L$. and E. tetralix L. J. Ecol. 60:131-140.

Kennedy, R.A., M.E. Rumpho, and T.C. Fox. 1992. Anaerobic metabolisms in plants. Plant Physiol. 100:1-6.

Kozlowski, T.T. 1984. Extent, causes, and impact of flooding, P. 1-5. In: T.T. Kozlowski (ed.). Flooding and plant growth. Academic Press, London.

Leul, M. and W.J. Zhou. 1999. Alleviation of waterlogging damage in winter rape by uniconazole application: Effects on enzyme activity, lipid peroxidation, and membrane integrity. J. Plant Growth Regul. 18:9-14.

Lin, K.H., C.C. Weng, H.F. Loa, and J.T. Chen. 2004. Study of the root antioxidative system of tomatoes and eggplants under waterlogged conditions. Plant Sci. 167:355-365.

Marcum, K.B. 1998. Cell membrane thermostability and whole-plant heat tolerance of Kentucky bluegrass. Crop Sci. 38:1214-1218.

Naidoo, G., K.L. McKee, and I.A. Mendelssohn. 1992. Anatomical and metabolic responses to waterlogging and salinity in Spartina Alterniflora and S. Patens (Poaceae). Amer. J. Bot. 79:765-770.

Olivella, C., C. Biel, M. Vendrell, and R. Save. 2000. Hormonal and physiological responses of Gerbera Jamesonii to flooding stress. HortScience 35:222-225.

Ota, Y. 1970. Diagnostic method for measurement of root activity in rice plant. Jpn. Agr. Res. Qrtly. 5:1-6.

Razmjoo, K., S. Kaneko, and T. Imada. 1993 Varietal differences of some cool-season turfgrass species in relation to heat and flood stress. Int. Turf. Res. J. 7:636-642.

Sapra, V.T. and A.O. Anaele. 1991. Screening soybean genotypes for drought and heat tolerance. J. Agron. Crop Sci. 167:96-102.

SAS Institute. 1987. SAS user's guide: Statistics. 6th ed. SAS Inst, Cary, N.C.

Schravendijk, W.-V. and O.M. Van Andel. 1986 The role of ethylene during flooding of Phaseolus vulgaris. Physiol. Plant. 66:257-264.

Simon, E.W. 1974. Phospholipids and plant membrane permeability. New Phytol. 73:377-420.

Su, P.H., T.H. Wu, and C.H. Lin. 1998. Root sugar level in luffa and bitter melon is not referential to their flooding tolerance. Bot. Bull. Acad. Sin. 39:175-179.

Waddington, D.V. and J.H. Baker. 1965. The influence of soil aeration on the growth and chemical composition of three grass species. Agron. J. 57:253-258.

Ye, Y., F.Y. Nora Tam, Y.S. Wong, and C.Y. Lu. 2003. Growth and physiological responses of two mangrove species (Bruguiera gymnorrhiza and Kandelia candel) to waterlogging. Environ. Exp. Bot. 49:209-221.

Zhang, J.H. and W.J. Davis. 1987. ABA in root and leaves of flooded pea plants. J. Expt. Bot. 38:649-659. 